\title{
РОЗРОБКА ТЕХНОЛОГІЇ ОТРИМАННЯ БІОКОМПОЗИТІВ НА ОСНОВІ ГЛЮТИНУ ТА ДЕРЕВНОГО БОРОШНА
}

\author{
V. KASHYTSKYI, O. SADOVA, N. SHUM \\ Lutsk National Technical University
}

\section{DEVELOPMENT OF TECHNOLOGY FOR OBTAIGNING OF BIOCOMPOSITES BASED ON BONE GLUE AND WOOD FLOUR}

\section{https://doi.org/10.36910/6775-2310-5283-2022-15-27}

Мета. Визначити температурно-часовий режим термічної обробки біокомпозитних матеріалів на основі глютину та деревного борошна, сформованих методом гарячого пресування композиції.

Методика. Біокомпозитні зразки формували методом гарячого пресування композииії, до складу якої входили глютиновий розчин та деревне борошно. Межу міџності при стисненні розраховували в результаті визначення максимального руйнівного навантаження циліндричних зразків діаметром 20 мм, які стискували за допомогою статичного навантаження з швидкістю переміщення нижньої траверси преса 2 мм/хв.

Результати. Полімеркомпозитні матеріали широко використовують для виготовлення виробів в різних галузях промисловості та техніки завдяки унікальним властивостям. Однак зростання рівня екологічного забруднення та зменшення запасів вичерпних ресурсів $\epsilon$ приводом для зниження інтенсивності використання полімеркомпозитів на основі синтетичних матриць та наповнювачів. Вирішення проблеми полягає у впровадженні компонентів природного походження, які є сумісними з навколишнім середовищем та здатні відновлюватися за рахунок щзорічного або ичилічного збору рослинної сировини. Волокна або порошкові матеріали рослинного походження після необхідної обробки є придатними для використання як наповнювачі біокомпозитних матеріалів, однак потребують вивчення процесів структурування системи для розробки технології формування виробів конструкиійного призначення.

Формування біокомпозитних виробів на основі глютину та деревного борошна доиільно проводити з використанням гарячого пресування, яке полягає у витримиі прескомпозииіі за температури $150{ }^{\circ} \mathrm{C}$ протягом 3 год з наступною термічною обробкою біокомпозитних виробів для видалення надлишкової вологи та завершення процесу структурування біополімерної матриці. В результаті отримано біокомпозитний матеріал, 
міцність при стисненні якого становить 45-47 МПа, щзо ијілком достатньо для виготовлення виробів конструкиійного або декоративного призначення.

Наукова новизна. Вперше застосовано технологію гарячого пресування композитної сумімі на основі біополімерного в'яжучого та порошкового наповнювача природного походження та визначено оптимальний режим термічної обробки біокомпозитних матеріалів, щзо дозволило отримати матеріал конструкиійного призначення з високою питомою мічнністю.

Практична значимість. Розроблені біокомпозитні матеріали дочільно використовувати для виготовлення тари, елементів декору салонів транспортних засобів, корпусів приладів та меблів, щзо дозволить розширити сировинну базу, вирішити проблему утилізачії відходів та покращити екологічну безпеку.

Ключові слова: розчин глютину, гаряче пресування, термічна обробка, міцність.

Постановка проблеми у загальному вигляді та їі зв'язок із важливими науковими чи практичними завданнями. На теперішній час біокомпозити впевнено витісняють класичні матеріали з традиційних сфер використання (вироби побутового призначення, корпуси приладів, будівельні матеріали, меблі, деталі салонів транспортних засобів), оскільки дозволяють вирішити ряд актуальних проблем, які стосуються зменшення ваги, підвищення екологічної безпеки та розширення сировинної бази. Синтетичні полімери наразі $\epsilon$ джерелом забруднення навколишнього середовища, що вже призводить до екологічної катастрофи, а також потребують використання сировини на основі вуглеводнів, вміст яких у земній корі суттєво знижується. Інтенсивне впровадження біокомпозитних матеріалів на основі полімерів та наповнювачів природного походження забезпечує вирішення екологічних проблем, що пов'язано з використанням відновних ресурсів та компонентів, які $\epsilon$ частиною природного середовища. Вдосконалення технологій формування та покращення властивостей біокомпозитних матеріалів забезпечить інтенсивне використання виробів на основі компонентів природного походження та призведе до часткової або повної відмови від експлуатації синтетичних полімерів на користь біокомпозитів. Такі підходи визначають актуальність досліджень в галузі розробки нових композитів на основі біополімерів та натуральних наповнювачів, оскільки потребують вивчення процесів формування біокомпозитних виробів, дослідження властивостей та структури розроблених біокомпозитних матеріалів.

Зазвичай технологія формування полімеркомпозитних матеріалів визначається властивостями синтетичного або біополімерного в'яжучого, а 
також видом та вмістом модифікаторів i наповнювачів. Розробка полімеркомпозитів нового хімічного складу потребує вивчення структури та властивостей композитів залежно від впливу технологічних факторів, що дозволить проводити формування бездефектних виробів 3 врахуванням особливостей фазових перетворень під впливом зовнішніх фізичних полів.

Використання біополімерної матриці передбачає використання пресового обладнання та підвищеної температури формування виробів, що містять в якості наповнювача деревне борошно. Підготовлену композицію піддають пресуванню та термічній обробці, режим якої визначається вмістом та хімічним складом наповнювачів, що потребує дослідження особливостей структурних перетворень біополімерної матриці та вивчення процесів взаємодії компонентів між собою.

Аналіз останніх досліджень, у яких започатковано вирішення проблеми. Полімеркомпозити на основі синтетичних волокон та полімерних матриць майже не піддаються переробці, що призводить до накопичення промислових відходів та відпрацьованих виробів в навколишньому середовищі. Найкращою альтернативою синтетичним волокнам виступають рослинні волокна, які входять до складу біокомпозитних матеріалів $[1,2]$. Натуральні волокна після спеціальної обробки здатні виконувати армувальну функцію, що забезпечує підвищення фізико-механічних та експлуатаційних характеристик біокомпозитних матеріалів, які вирізняються невисокою собівартістю, низькою питомою вагою та належать до класу екологічно безпечних матеріалів.

Розширення асортименту виробів на основі біокомпозитних матеріалів, які містять природні компоненти з відновлюваних джерел, інтенсивно зростає, що обумовлено гострою необхідністю розвивати напрямок екологічно стійких технологій та обмеженням сировинних ресурсів, які використовують для виготовлення синтетичних полімерних волокон або матриць $[3,4]$. У багатьох випадках біоматеріали з натуральними волокнами мають багато переваг перед синтетичним, оскільки забезпечують зниження ваги виробу за рахунок низької щільності матеріалу, задовільну питому міцність, додаткову функціональність (демпфування, поглинання ударів), підвищення безпеки праці за рахунок використання екологічно безпечних технологій, активацію процесів природовідновлення в результаті біосеквестрації вуглекислого газу та здатності до біологічного розкладання.

У біокомпозитах, які армовані волокнами природного походження, відбувається підвищення міцності та жорсткості композитного матеріалу. 
Встановлено, що натуральні волокна (кенаф, льон, джут, конопля та сизаль), викликають значний науковий та практичний інтерес, оскільки такі наповнювачі дозволяють отримати біокомпозити з високими механічними характеристиками та $є$ замінниками скловолокна в автомобільній промисловості. Композити 3 натуральних волокон сої були використані в комерційних цілях для виготовлення панелей кузова та даху кабін сільськогосподарської техніки [5]. Деталі виготовляються за технологією реакційного лиття під тиском (RIM), що забезпечує зменшення ваги до $25 \%$.

Досить поширеним методом формування біокомпозитних виробів, що мають вісь обертання, $є$ процес намотування натурального волокна на оправку. Під час формування виробу безперервна нитка попередньо просочена смолою намотується в декілька шарів під різними кутами для підвищення тріщиностійкості виробів [6]. Цей метод використовується в поєднанні 3 методом вакуумного формування, що дозволяє інтенсифікувати процес виготовлення виробів без дефектів структури. При вакуумному формуванні оправку з просочених смолою волокнами спочатку поміщають у вакуумну камеру, що змушує оболонку опускатися на поверхню під тиском 1 бар, а потім конструкція поміщається в піч для тверднення смоли.

Біокомпозитні матеріали, що містять наповнювачі дисперсного типу на основі крохмалю та дискретних целюлозних волокон, доцільно формувати методом гарячого пресування [7, 8]. Суміш біополімерного в'яжучого та дискретних целюлозних волокон піддають змішуванню для забезпечення високого ступеня однорідності, а потім сушать на повітрі або у вакуумі. Біокомпозитні вироби отримують пресуванням за постійної температури $140{ }^{\circ} \mathrm{C}$ і тиску від 10 МПа до 50 МПа. При цьому міцність на згин та модуль пружності збільшуються у випадку збільшення тиску пресування.

Вироби на основі біокомпозитів, що містять дискретні натуральні волокна, формують також шляхом лиття під тиском або екструзії. При цьому біокомпозитні композиції на основі крохмалю, що містять 50 \% натуральних волокон (коноплі, льону або деревини) обробляють методом лиття під тиском, а у випадку введення волокон у кількості 60-70\% використовують метод екструзії. В якості матриці використовують термопластичні полімери на біологічній основі, такі як PLA (полімолочна кислота), крохмаль і лігнін, які у поєднанні з натуральними волокнами забезпечують підвищення жорсткості і термічної стабільності біокомпозитів [9]. 
Цілі статті. Визначення стадійності та температурно-часового режиму термічної обробки композиції, прескомпозиції та пресованого біокомпозиту 3 високим ступенем наповнення системи для виготовлення виробів конструкційного призначення.

Об'єкт дослідження. Біокомпозитний матеріал конструкційного призначення на основі глютину (100 мас.ч.) та деревного борошна (100 мас.ч.), формування якого відбувається методом гарячого пресування.

Методи дослідження. Технологічний процес формування біокомпозитних зразків включає стадії підготовки та дозування компонентів, змішування та сушіння композиції, пресування та термічної обробки прес-композиції, термічної обробки пресованого композиту.

Межу міцності при стисненні біокомпозитних зразків визначено за ДСТУ EN ISO 604:2019. Пластмаси. Визначення властивостей під час стискання. Циліндричні зразки діаметром $20 \pm 0,5$ мм і висотою 30 мм піддавали стиску при рівномірному зростаючому навантаженні 3 швидкістю наближення траверси преса 2 мм/хв.

Виклад основного матеріалу дослідження 3 повним обгрунтуванням отриманих наукових результатів. Композицію готували шляхом механічного змішування розчину глютину 3 деревним борошном. Надалі композицію поміщають в порожнину прес-форми і піддають стискуванню (5-6 МПа), після чого прес-форму поміщають в сушильну камеру і проводять термічну обробку $\left(\mathrm{TO}_{1}\right)$ в діапазоні температур $110-150{ }^{\circ} \mathrm{C}$ (табл. 1). Видалення виробу проводять після охолодження прес-форми до температури $18-20{ }^{\circ} \mathrm{C} \quad 3$ наступною термічною обробкою $\left(\mathrm{TO}_{2}\right)$ за температури $150{ }^{\circ} \mathrm{C}$ протягом 2 год (рис. 1).

Рис. 1. Загальний вигляд біокомпозитного зразка 
На першому етапі термічну обробку прескомпозиції в прес-формі доцільно проводити за ступінчастим режимом 3 нагріванням до температури $110{ }^{\circ} \mathrm{C}$ протягом однісї або двох годин та наступним підвищенням температури до $150{ }^{\circ} \mathrm{C}$ протягом двох або трьох годин. При цьому відбувається поступове нагрівання в'яжучого 3 підвищенням розчинності глютину, що призводить до змочування частинок деревного борошна та утворення хімічних зв'язків між компонентами. Встановлено, що підвищення тривалості витримки прескомпозиції за ступінчастим режимом 1-4 (табл. 1) до п’яти годин призводить до зниження міцності при стисненні біокомпозитів у 2,2 рази.

Таблиця 1. Температурно-часові режими формування біокомпозитів

\begin{tabular}{|c|c|c|c|c|c|}
\hline \multirow{2}{*}{ № } & \multicolumn{2}{|c|}{$\begin{array}{c}\text { Термічна обробка } \\
\text { прескомпозиції }\left(\mathrm{TO}_{1}\right)\end{array}$} & \multicolumn{2}{|c|}{$\begin{array}{c}\text { Термічна обробка пресованого } \\
\text { біокомпозиту }\left(\mathrm{TO}_{2}\right)\end{array}$} & \multirow{2}{*}{$\begin{array}{c}\text { Межа } \\
\text { міцності при } \\
\text { стисненні, } \\
\text { МПа }\end{array}$} \\
\hline & $\begin{array}{l}\text { Температура, } \\
{ }^{\circ} \mathrm{C} \\
\end{array}$ & $\begin{array}{l}\text { Тривалість } \\
\text { обробки, год }\end{array}$ & Температура, ${ }^{\circ} \mathrm{C}$ & $\begin{array}{c}\text { Тривалість } \\
\text { обробки, год }\end{array}$ & \\
\hline \multirow{2}{*}{1} & 110 & 1 & \multirow{2}{*}{150} & \multirow{2}{*}{2} & \multirow{2}{*}{22,9} \\
\hline & 150 & 2 & & & \\
\hline \multirow{2}{*}{2} & 110 & 2 & \multirow{2}{*}{150} & \multirow{2}{*}{2} & \multirow{2}{*}{17,5} \\
\hline & 150 & 2 & & & \\
\hline \multirow{2}{*}{3} & 110 & 1 & \multirow{2}{*}{150} & \multirow{2}{*}{2} & \multirow{2}{*}{11,9} \\
\hline & 150 & 3 & & & \\
\hline \multirow{2}{*}{4} & 110 & 2 & \multirow{2}{*}{150} & \multirow{2}{*}{2} & \multirow{2}{*}{10,4} \\
\hline & 150 & 3 & & & \\
\hline 5 & 150 & 2 & - & - & 23,9 \\
\hline 6 & 150 & 2 & 150 & 1 & 26,1 \\
\hline 7 & 150 & 2 & 150 & 2 & 30,3 \\
\hline 8 & 150 & 2 & 150 & 3 & 26,3 \\
\hline \multirow{3}{*}{9} & 110 & 1 & \multirow{3}{*}{150} & \multirow{3}{*}{2} & \multirow{3}{*}{28,2} \\
\hline & 150 & 2 & & & \\
\hline & \multicolumn{2}{|c|}{ + стиснення } & & & \\
\hline \multirow{3}{*}{10} & 110 & 1 & \multirow{3}{*}{150} & \multirow{3}{*}{2} & \multirow{3}{*}{47,7} \\
\hline & 150 & 3 & & & \\
\hline & \multicolumn{2}{|c|}{ + стиснення } & & & \\
\hline
\end{tabular}

Це пов'язано із видаленням частини в'яжучого з об'єму прескомпозиції під впливом теплової енергії, яка підвищує рідкотекучість розчину глютину. Втрата частини біополімерного в'яжучого призводить до утворення порожнин, які залишаються після охолодження і наступна термічна обробка біокомпозитів не забезпечує підвищення щільності та відновлення суцільності матеріалу. При цьому підвищення тривалості обробки прескомпозиції призводить до 
антибатного зниження міцності при стисненні біокомпозитів, що пов'язано із поступовим зниженням вмісту в'яжучого в процесі термічної обробки.

Проведення термічної обробки на першому етапі за температури $150{ }^{\circ} \mathrm{C}$ протягом 2 год без обробки на другому етапі (режим 5) забезпечує аналогічні значення межі міцності при стисненні, які отримано у випадку обробки за режимом 1 (табл.1). Це пов'язано із невисокою тривалістю обробки (2 год), що дозволило зберегти в об'ємі прескомпозиції достатню кількість в'яжучого.

Проведення термічної обробки на другому етапі дозволило підвищити межу міцності біокомпозитів на 8 \% у випадку витримки зразків протягом 1 год (режим 6) та на 20 \% у випадку витримки 2 год (режим 7). Підвищення міцності пов'язано із видаленням надлишкової вологи, що призводить до рівномірного утворення хімічних зв'язків між поверхнею частинок деревного борошна та макромолекулами глютину. Підвищення тривалості обробки до 3 год (режим 8) призводить незначного зниження міцності, оскільки відбувається формування напруженого стану.

Вирішення проблеми появи порожнин у випадку видалення біополімерного в'яжучого під час першого етапу термічної обробки полягає у застосуванні додаткового стиснення після завершення витримки за підвищеної температури (режим 9-10). Це забезпечує наближення локальних об'ємів біокомпозитного матеріалу, які були розділені за рахунок втрати частини в'яжучого, 3 відновленням суцільності матеріалу, що призводить до підвищення міцності. В даному випадку підвищення тривалості обробки до 3 год на першому етапі термічної обробки (режим 10) призводить до підвищення міцності на $40 \%$ порівняно 3 режимом 9, оскільки більша тривалість обробки з наступним пресуванням композиції забезпечує додаткове видалення вологи та утворення хімічних зв'язків.

Висновки та перспективи подальших досліджень. У роботі визначено, що підвищення тривалості витримки до 5 год на першому етапі термічної обробки призводить до зниження у 2-2,2 рази міцності при стисненні, оскільки відбувається утворення порожнин в результаті інтенсивного видалення біополімерного в'яжучого через нещільності прес-форми. В результаті утворюється пориста структура біокомпозитного матеріалу з великою кількістю розшарувань та дефектів структури, які виступають концентраторами напружень та джерелом зародження тріщин.

Застосування після першого етапу термічної обробки додаткової операції пресування композиції, що перебуває в нагрітому стані, забезпечує відновлення 
цілісності матеріалу за рахунок утворення хімічних зв’язків між компонентами. Підвищення межі міцності при стисненні біокомпозитного матеріалу на $40 \%$ відбувається у випадку застосування термічної обробки на першому етапі протягом 3 год, що забезпечує видалення вологи та формування структури 3 рівномірним розподілом макромолекул матриці.

В подальшому планується провести визначення впливу вологи на інтенсифікацію процесів термічної обробки прескомпозиції, що визначає тривалість технологічного процесу формування біокомпозитних виробів.

\section{Список використаних джерел}

1. Takagi H., Winoto C.W. Netravali A.N. Tensile Properties of Starch-based Green Composites Reinforced with Randomly Oriented Discontinuous MAO Fibres, International Workshop on Green Composites. Japan, 2002. PP. 4-7.

2. Economic and environmental concerns of bio-based polymers processing. Khalid Mahmood Zia, Muhammad Usman Akbar. Processing Technology for Bio-Based Polymers. 2021.

3. Quarshie R., Carruthers, J. Technology overview biocomposites. 2014. 40 p.

4. Patil A.Y., Banapurmath N.R., Yaradoddi J.S., Kotturshettar B.B., Shettar АюS., Basavaraj G.D., Keshavamurthy R., Yunus Khan T.M., Mathad S.N.. Experimental and Simulation Studies on Waste Vegetable Peels as Bio-composite Fillers for Light Duty Applications. Arabian Journal for Science and Engineering. 2019. P. 326-345.

5. Wool, R.P., Sun, X.S. Bio-Based Polymers and Composites. Elsevier, 2005. 620 p. ISBN: 9780080454344

6. Ganesh D. Shrigandhi, Basavaraj S. Kothavale. Biodegradable composites for filament winding process. Materials Today: Proceedings. 42(9). 2021. 7 p. DOI:10.1016/j.matpr.2020.12.718

7. Sarasini F. Thermoplastic biopolymer matrices for biocomposites. Biocomposites for HighPerformance Applications. 2017. PP. 81-123.

8. Кашицький В.П. та ін. Оптимізація складу та технології формування біокомпозитів на основі крохмального в'яжучого. Наукові нотатки. Випуск 71. Луцьк, 2021. С. 353-359.

9. Zafeiropoulos N.E. Interface Engineering of Natural Fibre Composites for Maximum Performance. India, 2011. 414 p.

\section{References}

1. Takagi H., Winoto C.W. Netravali A.N. Tensile Properties of Starch-based Green Composites Reinforced with Randomly Oriented Discontinuous MAO Fibres, International Workshop on Green Composites. Japan, 2002. PP. 4-7.

2. Economic and environmental concerns of bio-based polymers processing. Khalid Mahmood Zia, Muhammad Usman Akbar. Processing Technology for Bio-Based Polymers. 2021.

3. Quarshie R., Carruthers, J. Technology overview biocomposites. 2014. 40 p.

4. Patil A.Y., Banapurmath N.R., Yaradoddi J.S., Kotturshettar B.B., Shettar AюS., Basavaraj G.D., Keshavamurthy R., Yunus Khan T.M., Mathad S.N.. Experimental and Simulation Studies on Waste Vegetable Peels as Bio-composite Fillers for Light Duty Applications. Arabian Journal for Science and Engineering. 2019. P. 326-345. 
5. Wool, R.P., Sun, X.S. Bio-Based Polymers and Composites. Elsevier, 2005. 620 p. ISBN: 9780080454344

6. Ganesh D. Shrigandhi, Basavaraj S. Kothavale. Biodegradable composites for filament winding process. Materials Today: Proceedings. 42(9). 2021.7 p. DOI:10.1016/j.matpr.2020.12.718

7. Sarasini F. Thermoplastic biopolymer matrices for biocomposites. Biocomposites for HighPerformance Applications. 2017. PP. 81-123.

8. Kashytskyi V.P. ta in. Optymizatsiia skladu ta tekhnolohii formuvannia biokompozytiv na osnovi krokhmalnoho v'iazhuchoho. Naukovi notatky. Vypusk 71. Lutsk, 2021. S. 353-359.

9. Zafeiropoulos N.E. Interface Engineering of Natural Fibre Composites for Maximum Performance. India, 2011. 414 p.

Purpose. Determine the temperature-time mode of heat treatment of biocomposite materials based on glutin glue and wood flour formed by hot pressing of the composition.

Method. Biocomposite samples formed by hot pressing of composition consisting of glutin glue solution and wood flour. The compressive strength calculated by determining the maximum destructive load of cylindrical samples with a diameter of $20 \mathrm{~mm}$. The samples compressed by static loading with a speed of movement of the lower traverse of the press $2 \mathrm{~mm} / \mathrm{min}$.

Results. Polymer composite materials are widely used for the manufacture of products in various industries and technics due to their special properties. However, the growing level of environmental pollution and declining reserves of exhaustible resources is a reason to reduce the intensity of the use of polymer composites based on synthetic matrices and fillers. The solution is to introduce components of natural origin that are compatible with the environment and can be restored through annual or cyclical collection of plant materials. Processed fibers or powder materials of plant origin are suitable for use as fillers for biocomposite materials, but require study of the processes of structuring of system to develop technology for forming structural products.

The formation of biocomposite products based on glutin glue and wood flour carried out using hot pressing, which consists in aging press-compositions at a temperature of $150^{\circ} \mathrm{C}$ for $3 \mathrm{~h}$. During heat treatment, excess moisture removed and the process of structuring the biopolymer matrix is completed. The result is a biocomposite material with a compressive strength of 45-47 $\mathrm{MPa}$, which is sufficient for the manufacture of the structural or decorative products.

Scientific novelty. For the first time the technology of hot pressing of composition based on biopolymer binder and powder natural filler used. For the first time, the optimal mode of heat treatment of biocomposite materials was determined, which allowed to obtain a structural material with high specific strength.

Practical significance. The developed biocomposite materials used for the manufacture of containers, decor elements of vehicle interiors, device housings and furniture. This will expand the raw material base, solve the problem of waste disposal and improve the environmental condition.

Keywords: glutin glue solution, hot pressing, heat treatment, strength.

Рекомендовано до публікаиії доктором .технічних наук, професором Луиького НТУ Рудьом В.Д Дата надходження в редакиію 28. 12. 2021 